\title{
DEVELOPING RELATIONS WITH CUSTOMERS: PRESENTATION OF DIFFERENT VIEWPOINTS
}

\author{
Alena Piknová1
}

\begin{abstract}
The theme of customer relations management is constantly being developed. The goal of this paper is to provide insight regarding customer relations from multiple viewpoints. This paper collates the recent information on the subject. Based on all entries, the most important factor for both the customer, and more so, the retailer, is customer satisfaction. The most important relates to the human being. The study examines research results of various authors and study identifies possible risks arising from the interaction of providing services and goods.
\end{abstract}

UDC Classification: 658.8, DOI: http://dx.doi.org/10.12955/cbup.v4.739

Keywords: customer relations, values, customer satisfaction, long-term relations.

\section{Introduction}

Operating a business, working with people, and maintaining peer and partner relationships, are mutually combined. Enterprises realize the importance of these for successful progression of their business. Customer relations involve building upon a base of intuition and social skills. This natural way is frequently effective and desired by customers. The leader has a position to indoctrinate the surroundings with a unique spirit or a corporate culture.

The importance of sound customer relations is felt by entrepreneurs in the form of valuable references and by keeping the customer in further purchases and improvement of relations. This is the reason entrepreneurs are interested in relationships and their improvement.

Customer relations involve risks, which can threaten business and potentially terminate business relations. For these reasons, this study examines risks arising from the interaction of providing services and goods.

\section{Relations Based on Interaction}

The study first examines the relationship between a customer and a retailer as an interaction.

The perception of a customer as one buying products is not the most beneficial for long-term relation development for all involved. Possibly, a better way is to develop relations based on cooperation and considering the customer as a human being rather than a company. Customers are people, who make decisions and with whom business owners converse and build relations. This is supported by the statement: "Since successful sales is mainly based on building pleasant feelings, I suggest to focus on creating partnerships on the base of transparency and honesty, which creates the space for mutual development" (Manažér, 2015, p. 13).

A supplier could err by considering increased sales turnover only through increasing customer quantity. Considering only the fulfilment of orders and claims of the dominant party is a risk. Cooperation provides many possibilities to improve products and find new innovations. One can fulfill the needs correctly only by knowing them precisely.

Lesáková (2009), by showing opinions of multiple authors (Payne, Davidson, Hooley, and Saunders), suggested that the relation of a company with a customer (as an entity) cannot be created nor persist. Lesáková (2009) concluded that relations can only persist between individuals. This knowledge can be used in planning sales formats.

Developing interaction between a customer and a retailer can be assisted by the work of Triznová (2014), which analyzed the company-customer relation and compared opinions of multiple authors with the common idea of relation being interaction. The writer suggested the idea was not relevant

${ }^{1}$ Alena Piknová, Vysoká škola manažmentu, City University of Seattle, Bratislava, Slovak Republic, alena.piknova@gmail.com 
whether exchanging products, services, or exchanging, and proposed a better explanation based on the ideas of the Nordic school, which according to Triznová (2014) claimed the quality of interactions are determined by the following areas:

1. World of values in aesthetics, epics, ethics, and emotions;

2. Economic world in economics, and effectivity; and

3. Human world in energy, enthusiasm, and education.

These areas cover the field of interaction between a company (salesman) and a customer. These three worlds provide information based on the qualitative evaluation of the customer and the acceptance or refusal of the company as occurs with customer relations. The author further noticed that the relation building process consisted of many encounters and stages.

The relations between two parties require development. Lesáková (2009) divided the life cycle of customer relations into three stages:

1. Establishing relations;

2. Maturity and threat; and

3. Revitalization.

However, the author warned that the quality of encounters determined the length of each stage and the relationship as a whole.

\section{Relations Based on Moral Values}

Moral values are held long-term on a personal level. They surface with behavior during personal interactions. In a customer-oriented society, the relationship's nucleus is the person and that person's morality. The moral values of employees define the working atmosphere. The following will focus on three pillars of moral relations: devotion, loyalty, and customer satisfaction.

\section{Customer Devotion}

We present opinions of three different authors, considered to describe customer loyalty the most cogently. According to Karlíček and Petr (2011), customers build devotion from two factors. One is the supplier's knowledge of their customer's needs, which are bound by mutual business history, and allows the supplier to solve the customer's problem or to offer an alternative. The second factor is the willingness of the supplier to find a solution and promptly solve the case to satisfy the customer when the problem occurs. The customer then perceives that changing their supplier means ending this worthwhile relationship and is not confident of finding a similar one elsewhere. The supplier's communication creates value, which the consumer recognizes.

Notwithstanding these statements, it is known that long-term customers comprise an environment for superior progress and enriched relations.

Customer Loyalty

Some customers continue buying products although they are unsatisfied with them. They remain loyal to the supplier. Customer evaluates their situation, supported by loyalty (Trnková, 2009). It is defined as "devotion, positive attitude; according to social psychologists a person is unable to be honestly loyal to more than two people, groups or movements" (Hartl, Hartlová, 2000, p. 295). This is important when realizing relations.

The crucial part to customer's loyalty was emphasized by Shuller's words: "Complete, engaged and loyal employees, as well as keen, devoted customers - not products and offers - are the strategic factor of a company's success" (Trnková, 2009, p. 8).

One possible condition for an organization to gain such loyal customers is to have loyal employees.

Customer Trust

Rather than talking about trust, is better to create it through one's behavior, through keeping promises. More important than a human need to trust someone, is the human need of feeling trusted by others. Examples from sociological studies are given by Cram (2012), who also included examples of trust 
from the economic field, and showed that in countries suffering from poverty, a high degree of mistrust was usually generated against foreign people.

Nevertheless, socialization and cooperation are a natural essence of the human psyche, despite the need to compete. Trust creates mutual bonds between people and trust is repaid with trust. Internet sales is a specific environment, since it lacks personal contact, trust is slower to develop. The factors for growing trust in this environment are branding, certifications, flexible cancelation policies, warranty conditions, money back guarantees, and excellent services.

\section{Customer Satisfaction}

The customer expresses satisfaction through loyalty and devotion to the supplier. Companies use many ways to acquire and retain customers. With the influence of the human factor, a relationship is developed between the two parties. One can never document or copy a relationship, or a communication, as it is too personal. However, it is possible to transfer information.

Cram (2012) mentions the research of the Japanese professor, Noriki Kano, who found that when analyzing services, it was necessary to analyze the technical component separate from the level of customer satisfaction. Kano recorded situations where the customer remained unsatisfied even after having their needs met. Kano divided the factors that affect customer satisfaction into performance, arousing delight, and basic requirements.

\section{Relations as a Competitive Advantage}

When intending to approach an organization or a customer as a supplier, it is best to have a competitive advantage. This can be gained by enhanced knowledge of the status, needs, values, and goals of the consumer, gained from new knowledge and experience of the supplier. To achieve a competitive advantage, it is necessary to have advanced knowledge of one's possibilities and drawbacks, the customer's situation and expectations, the competition, and the whole macro- and micro-sphere of the market. "If you don't know what the customer needs, very quickly they can go to a competitor who understand them better." (Kuchař, 2012, p. 11)

As has been shown many times in business, building long-term relations with customers is important. It is important to develop relations from both sides, with decreased interest, as much as possible, in gaining from the other for one's own profit. Salespeople, who are well trained on how to persuade the customer and mesmerize them with learned phrases in every occasion are easily recognized. On one hand, this salesperson discourages the customer. On the other hand, through these escalated relations, the customer can negotiate a lower price or free goods and services, without regard or respect towards the supplier. The responsibility for creating valuable relations lies with both participants.

Burger (2010) divided organizations into those focusing on their competitive strategies, those focused on customer service, those on the product, and those on the price. These are the capabilities that organizations use in relations to influence customers.

Relations as a Process

The next viewpoint is development of relations as a process.

Authors, such as, Vaculík and Kruppa (2006), referred to customer relations in three dimensions: information, conversations, and emotions. As a process, the importance is on the perception of the company. Furthermore, where the company has a product to offer the customer, one that fulfills its value, it is unimportant whether it is a product or a service as the product is the relation and the process between the participating parties. Because products are perceived as processes, their value is perceived as an integral part of the relations.

Based on the perception of offering a product as a process, for customer relations, constant product innovation is not important to maintain value for the customer. However, the development of customer relations is perceived as an innovation. The relations process has a competitive advantage. Even multiple sales of the same product to many customers can be unique every time. 
To create functioning customer relations, as described by Vaculík and Kruppa (2006), it is necessary for the organization (supplier) to build upon its experience, skillfulness, and know-how. Their recognition for having a suitable method for customer relations defines the competitive advantage. On all three levels, building relations depends on the cooperation of both parties.

Possibilities of Risk in Customer Relations

The following paragraphs present a number of effects that could worsen the relations between a company and its customers, despite their positive intentions.

\section{Unified Standard to Customer Interaction}

According to research into customer demands, the perfect customer approach requires the company's behavior to be homogeny, and for all employees to approach the customer in an informed and professional way. The employees of some companies must comply with a unified model in customer approach. The contrary, that emerges by an ambition for the best possible customer approach, is for a universal approach towards all customers. By universal approach, a space for individualization of customer approach is created. An impromptu opportunity for an exceptional gift or discount is foregone (Cram, 2012).

Kuchař (2012) showed an example for improving communication. Instead of the usual phrase used for customer approach in a store, "Good day, how can I help you?", (Kuchař, 2012) suggested it is more creative to approach the customer with: "Good day, have you ever been here before?" (Kuchař, 2012). When the answer was no, the salesperson then has the opportunity to introduce the shop to the customer and allow the customer the possibility of mentioning the reason for visiting the shop. Thus, the salesperson can learn the customer's needs and react in a targeted way. When the answer is yes, the salesperson can talk about the new product assortment, discounts, and news about the shop in general (Kuchař, 2012). This practical advice can provide several advantages in the sales field.

\section{Long-Term Relations Do Not Fit Every Customer}

When creating customer relations with a long-term focus, as previously mentioned, a long-term relationship is not always possible.

Lesáková (2009) explored the extent to which the customer wishes to be involved in the long-term development of relations with a company, and from research into 260 randomly selected and responding households on products such as, cars, and banking, insurance, and tourism offers, found the following:

- $23 \%$ of customers most probably maintain long-term relations with suppliers;

- $40 \%$ of customers want the possibility of relations with the suppliers but may not use such; and

- $37 \%$ of customers do not have a need for such relations.

The contribution of this research for the suppliers lies in the knowledge that there also exists a possibility that customers may not have long-time relations with the supplier.

\section{Conclusion}

This paper provided a closer look at customer relations from the viewpoints of supplier and customer, in terms of interaction, moral values, competitive advantage, and the process itself. Although the risks that can enter and affect relationships were not covered in full detail, several issues and paradoxes were included to provide a preview on the topic through various pre-selected "windows", considered to be of interest.

The supplier and customer interaction, by which the creation of partner relationship was emphasized, was important as an interaction between human beings. The customer does not create a relationship with a company, but rather relationships are created based on values, economic contribution, and the human factor (the uniqueness, energy and enthusiasm of a person). The moral values on which customer relations are built are most important in terms of dedication, loyalty, and trust, which relate to customer satisfaction. Relations as a source of competitive advantage require knowledge of every detail of the status, needs, and values of the customer, not for the purpose of profiting in sales alone, but for benefiting both sides. In the area of customer relations, value is displayed in the process, which 
evolves with each and every sales opportunity. The evolution of the relationship is perceived as an innovation with the attention focused on Customers Relation Management and the ability of the supplier to build it.

As different elements enter the customer relation process, they are used by companies to enhance the relations. One is loyalty cards with the sophistication of their use aimed at the need to collect customer information and increase sales potential. This generates significant risk for the customers, who do not perceive the threat and would rather avoid them.

Although building excellent relationships is the ultimate goal, risks can occur with the customer relations management. The universality of the customer approach can have a negative influence on the customer. Even a long-term relationship of the customer and supplier is not appealing to each and every customer, despite the customer being satisfied with the provided service.

The theme of customer and supplier is highly attractive, and its knowledge contributes to daily activities. It is eternally developing enabling further analysis and research into emerging new trends.

\section{References}

Burger, I. (2010). Špecialista pre rozvoj l’udských zdrojov. ibis partner. Školenie [Specialist in Human Resources Development. ibis partner. Training].

Cram, T. (2012). Vítězný tah. Jak dosáhnou prvotřídni úrovne služeb zákazníkum. Praha. [Winning move. How to reach world class levels of customer service. Prague.] CZ. Management Press. ISBN 978-80-7261-246-8.

Hartl, P., \& Hartlová, H. (2000). Psychologický slovník. Praha. Portál. [Psychological dictionary. Prague. Portal.] ISBN 807178-303-X, 295 (p.295).

Karlíček, M., \& Petr, P. (2011). Marketingová komunikace. Jak komunikovat na našem trhu. Praha. Grada. [Marketing communication. How to communicate in our market. Prague. Grada.] ISBN 978-80-247-3541-2.

Kuchař, V. (2012). Medonosný marketing. Brno. BizBooks. Praha. Albatros Media. [Melliferous marketing. Brno. BizBooks. Prague. Albatros Media.] ISBN 978-80-265-0024-7, 39-161 (p.11).

Lesáková, D. (2009). Postoje zákazníkov k CRM. In Rozšírenie teórie CRM: integrácia zákazníka do hodnotového ret’azca podniku. Ed Lesáková, D., Labská, H., Richterová, K., Lukačovičová, Z., Trnková-Vajsochová, Z. Zborník vedeckých statí. Ekonomická univerzita v Bratislave. Ekonóm. [Customer attitudes towards CRM. In theory Extending CRM: integration into the customer's value chain business. Ed Lesáková, D., Elbe, H. Richter K., Lukačovičová, Z., Trnkova-Vajsochová , Z. Proceedings of the scientific papers. University of Economics in Bratislava. Economist.]ISBN 978-80-225-2870-2, 5-24, 5878.

Manažér (2015). Všetci hovoria o tvorbe hodnoty, ale čo to vlastne je? In Bulletin Manažér. XX. 79. december 2015. ibis partner Slovakia [Everyone is talking about creating value, but what is it? In Bulletin Manager. XX. 79. December 2015. ibis partner Slovakia] (p.13)

Triznová, M. (2014). Manažment vzt’ahov so zákazníkom. Vedecká monografia. [Customer relationship management. Scientific monograph.] ISBN 978-80-228-2640-2.

Trnková, Z. (2009). Podstata a východiská lojality zákazníkov. Rozšírenie teórie CRM: integrácia zákazníka do hodnotového ret’azca podniku. Zborník vedeckých statí. Ekonomická univerzita v Bratislave. Ekonóm. [Fundamentals and Basis of customer loyalty. Extending the theory of CRM: customer integration in the value chain of the company. Proceedings of scientific papers. University of Economics in Bratislava. Economist.] ISBN 978-80-225-2870-2, 5-24, 5-24 (p.8).

Vaculík J., \& Kruppa M. (2006). Zásady riadenia vzt’ahov so zákazníkmi [The principles of customer relationship management]. Retrieved March, 11, 2016 from http://ks.utc.sk/casopis/pdf/old/I2006/vaculik.pdf ISBN 1336-8281, 57-61. 